\title{
Influence of algal population dynamics on phytoplankton colonization by bacteria: evidence from two diatom species
}

\author{
Dolors Vaqué $^{1, *}$, Carlos M. Duarte $^{2}$, Celia Marrasé ${ }^{1}$ \\ ${ }^{1}$ Instituto de Ciencias del Mar, Paseo Nacional s/n, E-08003 Barcelona, Spain \\ ${ }^{2}$ Centro de Estudios Avanzados de Blanes, Camino de Santa Bárbara s/n, E-17300 Blanes, Gerona, Spain
}

\begin{abstract}
Study of 2 diatom species, Leptocylindrus danicus and Skeletonema costatum, growing in an enclosed plankton community showed that most of the variability in the extent of epialgal colonization (i.e. bacteria algal cell ${ }^{-1}$ ) was attributable to differences within species, compared to small among-species and temporal variability. Within-species variability was related to the population dynamics of the diatom species examined, because the extent of colonization increased with the time algal cells had been exposed to colonization. Thus, modelling of algal colonization by bacteria requires both consideration of encounter probabilities and phytoplankton demography.
\end{abstract}

Bacterial colonization of algal surfaces is constrained by the probability of encounter between bacterial and algal cells, which determines the average number of epialgal bacteria (Vaqué et al. 1989). There is, however, great variability in the number of bacteria attached to coexisting algal cells (Vaqué et al. 1989) This variability is attributable to among- and withinspecies differences in algal susceptibility to bacterial colonization (Smith et al. 1989, Vaqué et al. 1989). In particular, the variability in bacterial colonization should be closely dependent on phytoplankton population dynamics, because actively growing phytoplankton cells should support a smaller load of attached bacteria than senescent ones (Kogure et al. 1982, Albright et al. 1986, Vaqué et al. 1989). This expectation is supported by the relatively intact surfaces and low DOC leakage of actively growing cells (Cole 1982, Bratbak 1987), and to the differences in the time the cells have been exposed to colonization (Vaqué et al. 1989), which depend on division rates.

Here we provide evidence of the importance of algal population dynamics for the development of variability

\footnotetext{
- Present address: Institute of Ecosystem Studies, The New York Botanical Garden, Mary Cary Flager Arboretum, Box AB, Millbrook, New York 12545-0129, USA
}

in the extent of bacterial colonization among coexisting algal cells. We first demonstrate the importance of within-species variability, relative to temporal and between-species variability, for the overall variability in the number of epialgal bacteria on 2 diatom species, Leptocylindrus danicus and Skeletonema costatum. We then examine the relationship between the population dynamics of the 2 diatom species and the development of within-species variability in the extent of bacterial colonization

These aspects were examined along a bloom and collapse episode of an enclosed marine phytoplankton community. We restricted our analyses to the 2 dominant diatom species because they were the only species found in sufficient abundance throughout the experiment to allow an adequate assessment of withinspecies variability in the extent of colonization by bacteria

Methods. The community used in the experiment was the natural phytoplankton community present in the Masnou Harbor $(20 \mathrm{~km}$ north of Barcelona, NW Mediterranean) in March 1988. The experimental microcosm was filled with $10 \mathrm{l}$ of seawater from the harbor, pre-filtered through a $150 \mu \mathrm{m}$ mesh nylon netting in order to remove large zooplankton. The experimental community was maintained at $20^{\circ} \mathrm{C}$ and illuminated at ca $270 \mu \mathrm{E} \mathrm{m}^{-2} \mathrm{~s}^{-1}$ for a $12: 12 \mathrm{~h}$ light-dark cycle. Samples were collected daily, at the onset of darkness, during the phytoplankton bloom and collapse episode ( 7 d) to determine algal and bacterial density. The density (cell $\mathrm{ml}^{-1}$ ) of the algal species considered here was determined under an inverted microscope on samples fixed with Lugol.

Free bacteria were separated from bacteria attached to particles by centrifugation at ca $600 \times \mathrm{g}$ for $10 \mathrm{~min}$ (Vaqué et al. 1989) prior to counting. The abundance of free bacteria was estimated by counting the bacteria in 

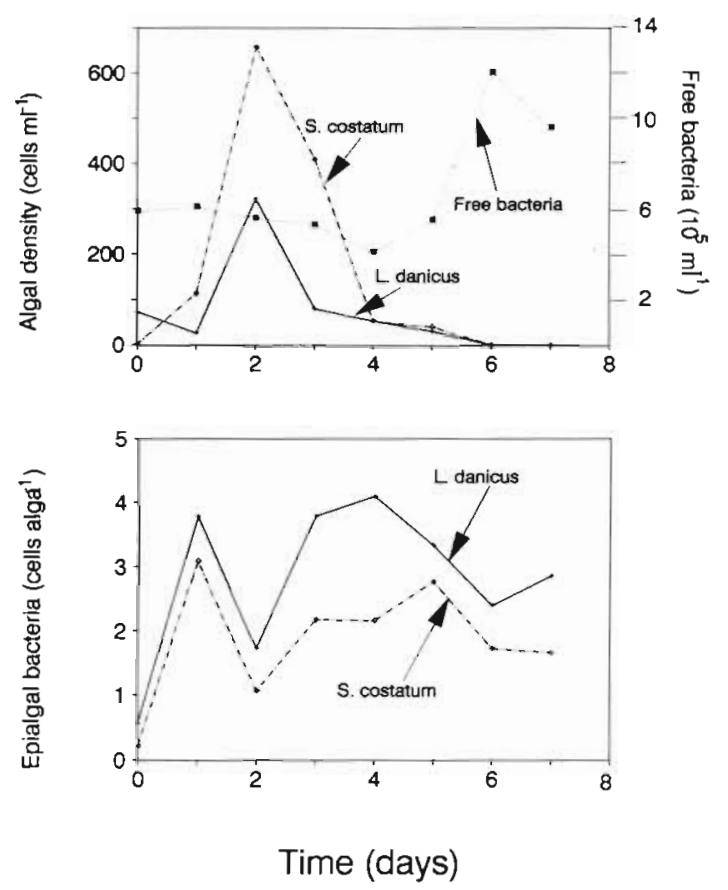

Fig. 1. Time course of algal and free-bacterial abundance (above), and the average number of epialgal bacteria per host cell (below)

an aliquot of the supernatant using epifluorescence microscopy (Nikon-ET microscope) following acridine orange staining and filtration through pre-stained (Sudan-Black) $0.2 \mu \mathrm{m}$ Nuclepore filters (Hobbie et al. 1977). The number of bacteria attached to cells of the 2 algal species considered was obtained as described in Vaqué et al. (1989). In each sample, we counted at least 300 to 400 free bacteria and the bacteria attached to 20 to 60 cells of each algal species. Because the number of epialgal bacteria was examined in a plane, the values reported here should correspond to about half the total epialgal bacteria per cell.

We used nested ANOVA to partition the variance in epialgal bacteria per algal cell into its temporal, between-species, and within-species components. The strength of relationships between variables was described using Pearson correlation coefficients.

Results. A bloom of the centric diatoms Leptocylindrus danicus and Skeletonema costatum, was followed by exponential growth of free bacteria $3 \mathrm{~d}$ after peak phytoplankton biomass (Fig. 1). The time-course of algal colonization by bacteria was similar for the 2 species considered ( $r=0.89, p<0.001$; Fig. 1 ), consistent with their similar population dynamics (Fig. 1). However, $L$. danicus cells (cell volume $2880 \mathrm{\mu m}^{3}$ ) supported a ca $50 \%$ greater load of epialgal bacteria (per cell) than $S$. costatum cells (cell volume $235 \mu^{3}$ ) throughout the experiment (Fig. 1), consistent with their larger cell size (cf. Vaqué et al. 1989).

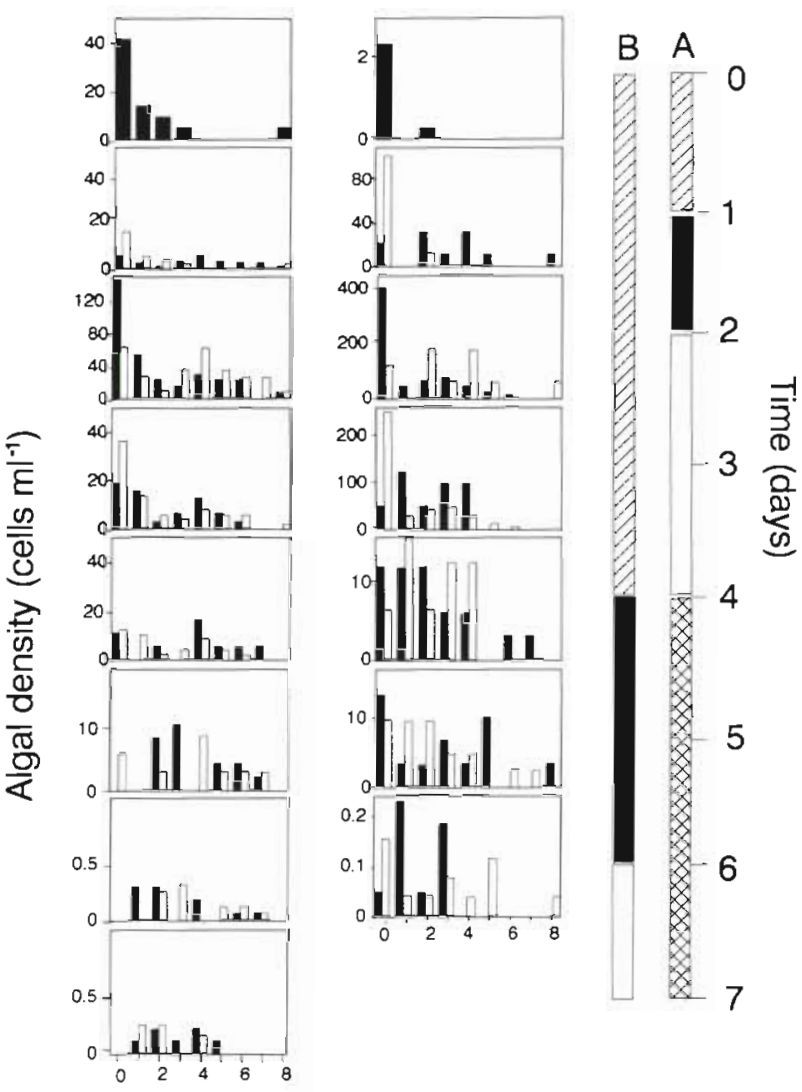

Epialgal bacteria (cells alga ${ }^{-1}$ )

Fig. 2. Leptocylindrus danicus (left) and Skeletonema costatum (right). Time course of the frequency distribution of the number of epialgal bacteria per algal cell. To assess changes in consecutive days, the observed distribution (black bars) is compared to that expected from conservation of the distribution in the previous day (open bars). Population development of (A) algae and (B) free bacteria are summarized as lag-phase (hatched), exponential growth (solid), population collapse (open), and resting stage (cross-hatched)

The overall similarity in the extent of bacterial colonization of these 2 species suggests that speciesspecific differences are, for these taxa, relatively unimportant in regulating algal colonization by bacteria. Moreover, nested ANOVA showed that the contribution of within-species variability to the overall variability in epiaigal bacteria per algal cells was much greater $(80 \% ; F=24.5, p<0.0001)$ than that of betweenspecies $(11 \% ; F=5.3, p>0.05$ ) or temporal (ca $8 \%$, $\mathrm{F}=3.5, \mathrm{p}>0.05)$ variability. The similar colonization dynamics experienced by the 2 species extends beyond the similarity in average values, because the timecourse of within-species variability, reflected in coefficients of variation between 60 and $320 \%$, was also coherent between the 2 species ( $r=0.73, p<0.05)$.

To best study the development of within-species variability in algal colonization, we examined the time- 
course of the frequency distribution of the number of epialgal bacteria per algal cell. This analysis showed significant deviations of the distribution observed on a particular day from that expected from the frequency distribution observed the preceding day (Fig. 2). Slow algal growth allowed rapid colonization during the first day (Fig.2), leading to the replacement of an initial population (i.e. time o) dominated by bacteria-free algal cells by a population dominated by algal cells supporting ca 3 attached bacteria cell ${ }^{-1}$ (Fig. 2). Exponential algal growth (Days 1 to 2; Fig. 1) resulted in the presence of numerous bacteria-free algae (Fig. 2) coinciding with peak algal density (Fig. 1). Conversely, subsequent algal population decline (Fig. 1) resulted in the dominance of heavily colonized $>2$ bacteria cell $^{-1}$ ) algal cells thereafter (Fig. 2)

Discussion. Our results stress the importance of within-species differences, over among-species differences, in algal colonization by bacteria. The dominance of within-species variability in our results derives, as shown by the time-course of algal colonization by bacteria (Fig.2), from the importance of algal population dynamics in regulating the colonization process. The results also provide insight into the time-scale of the colonization process, indicating that it is a highly dynamic process. Changes in the frequency distribution of epialgal bacteria (Fig. 2) follow from algal division and their subsequent colonization by bacteria. Rapid algal growth (i.e. division rates) during exponential growth leads to an increased frequency of algal cells with limited epialgal bacteria $1<2$ bacteria per cell) because (1) the algal surfaces have been exposed to colonization for a lower average time, and (2) the net result of algal division is to halve the number of epialgal bacteria on the resulting cells. Increased colonization derives both from the encounter between free bacteria and algal cells and, possibly, from bacterial division on the algal surface. Although the relative roles of these 2 processes cannot be inferred from the data on hand, the time course of the distribution of epialgal bacteria (Fig. 2) suggests that algal colonization is rather fast (e.g. 3 to 5 bacteria cell ${ }^{-1} \mathrm{~d}^{-1}$ between Samples 0 and 1; Fig. 2).
These results support our previous suggestion (Vaqué et al. 1989) that the epialgal bacteria load increases with the time the algal surfaces have been exposed to colonization (i.e. with decreasing phytoplankton growth rate). Because actively dividing phytoplankton cells, which are exposed to colonization for a shorter average time, are probably in better physiological condition than slow-growing cells, growth of bacteria attached to slow-growing cells may also benefit from greater DOC excretion (Albright et al. 1986). These 2 effects probably combine to generate an important influence of the average time phytoplankton surfaces have been exposed to colonization on the extent of algal colonization by bacteria. This needs be further studied to model the relationship between phytoplankton and their attached bacteria.

Acknowledgements. This research was supported by grants PR84-0061 and 88 HF343 of CICYT, Spanish Education and Science Ministry. We thank F. Vallespinós for encouragement and advice and M. Alcaraz and 2 anonymous reviewers for useful criticisms.

\section{LITERATURE CITED}

Albright, L. J., McRae, S. K., May, B. E. (1986). Attached and free-floating bacterioplankton in Howe Sound, British Columbia, a coastal marine fjord-embayment. Appl. environ. Microbiol. 51: 614-621

Bratbak, G. (1987). Carbon flow in an experimental microbial ecosystem. Mar. Ecol. Prog. Ser. 36: 267-276

Cole, J. J. (1982). Interactions between bacteria and algae in aquatic ecosystems. Ann. Rev. Ecol. Syst. 13: 291-314

Hobbie, J. E., Daley, R. J., Jasper, S. (1977). Use of Nuclepore filters for counting bacteria by fluorescence microscopy. Appl. environ. Microbiol. 33: 1225-1228

Kogure, K., Simidu, U., Taga, N. (1982). Bacterial attachement to phytoplankton in sea water. J. exp. mar. Biol. Ecol. 56: 197-204

Smith, R. E. H., Clement, P., Cota, G. F. (1989). Population dynamics of bacteria in Artic sea ice. Microb. Ecol. 17: $63-76$

Vaqué, D., Duarte, C. M., Marrasé, C. (1989). Phytoplankton colonization by bacteria: encounter probability as a limiting factor. Mar. Ecol. Prog. Ser. 54: 137-140

Manuscript first received: January 23, 1990

Revised version accepted: May 3, 1990 